\title{
Does A Formal Common-Basket Peg in East Asia Make Economic Sense? ${ }^{1}$
}

\section{INTRODUCTION}

Before the financial crisis, a number of east Asian economies managed their exchange rates with the aim of stabilising the value of their currency against a basket of key major currencies, but overwhelmingly the US dollar (Frankel and Wei 1994). This suited these economies in the first half of the $1990 \mathrm{~s}$ as the yen appreciated against the dollar, diverting trade and investment their way and stimulating economic growth. But as the dollar appreciated against the yen from 1995, these countries lost competitiveness relative to Japan and Europe, and their trading positions deteriorated, leaving them vulnerable to changes in investor sentiment.

This experience has been taken to show the folly of a country tying its currency to that of only one of its several major trading partners: so long as the major currencies move by large amounts against each other, a country which exports to all the major economies but targets stability only in its exchange rate with one major currency will experience variability in its effective exchange rate and its bilateral exchange rates with the other major currencies.

At the same time, trade within east Asia has become steadily more important to countries in the region. To the degree that the weights in an effective exchange rate target differ between countries, intra-regional exchange rates will also vary as the major currencies vary between themselves.

These two factors have led commentators, such as Williamson (1999), Dornbusch and Park (1999), Murase (2000) and others, to advocate a common-basket exchange rate peg for the east Asian region, or some subset of it. They argue that countries can expect to stabilise overall trade competitiveness by targeting such a peg. They also argue that countries can eliminate intra-regional exchange rate variability by adopting common weights in the basket peg: regional currencies move together so intraregional competitiveness is unchanged. This proposal seems to have engaged some interest at official levels in the region, especially in Japan (Council on Foreign Exchange and Other Transactions 1999; Sakakibara 1999; Kuroda 2000).

\footnotetext{
I would like to thank Marpudin for data support and Peter Drysdale, Arthur Grimes and David Vines for helpful comments. Responsibility for all errors is mine.
} 
This paper looks at some of the issues related to whether a formal commonbasket exchange rate peg would be appropriate for east Asia. It first summarises the current debate about common currency arrangements in the region. It then summarises the conceptual arguments for a common-basket exchange rate peg and assesses them with reference to a range of factors. Two are specific to the proposal. The first examines the degree to which trade patterns vary between countries in the region, to see whether particular countries would be disadvantaged relative to their neighbours under a common-basket peg. The other looks at the similarity of exports of countries within the region with those of their neighbours and the major economies. The argument for pegging to a common basket is less strong if the exports of countries within the region are more similar to those of the major economies than their regional neighbours.

A range of other factors is also relevant to assessing the likely robustness of a common-basket peg exchange rate regime. A common-basket peg would entail a change in exchange rate regime, and it is necessary to show that a peg would be superior to the current regime - floating exchange rates to which decision makers have already adapted. Advocacy of a shift to a common-basket peg presumes that exchange rate volatility adversely affects trade and economic performance, and evidence on this for east Asia is examined.

Pegging may also affect the adjustment of the real exchange rate, specifically whether it occurs through the nominal exchange rate or changes in the price level. The robustness of a regional exchange rate system depends not only on whether individual country's economic structures are similar, but also whether they pursue common policies and are subject to common internal and external shocks. This is assessed by identifying common factors and long-run or cointegrating relationships in regional real effective exchange rates.

Robustness of a regime also depends on a range of political factors whether the regime complements or conflicts with domestic policy objectives, whether countries are prepared to make substantive policy decisions collectively rather than preserve policy independence, and whether such a policy suits their strategic interests in the region. To the extent that outcomes under a common-basket peg conflict with national economic and policy interests, the system will be vulnerable to speculative attack. Accordingly, strong political commitment is essential. The arguments are summarised in the conclusion. 


\section{THE CURRENT DEBATE ON COMMON CURRENCY ARRANGEMENTS}

Most economists, especially those based in the United States, are highly sceptical about the scope for common currency arrangements in east Asia. Eichengreen and Bayoumi (1999), Bayoumi and Mauro (1999), Bayoumi, Eichengreen and Mauro (1999) and Mussa et al. (2000), for example, are dismissive of such arrangements in east Asia, particularly of the feasibility of monetary union. Japanese economists appear less sceptical (Goto and Hamada 1994; Ito, Ogawa and Sasaki 1998; Murase 2000; Ogawa and Ito 2000; Ogawa 2000; Kawai and Akiyama 2000; Kawai and Takagi 2000; Yoshino, Kaji and Suzuki 2000). It is probably wise to remember the words Robert Mundell (1961: 657) wrote 40 years ago about the unlikely event of currency union in Europe:

What is the appropriate domain of a currency area? It might seem at first that the question is purely academic since it hardly appears within the realm of political feasibility that national currencies would ever be abandoned in favor of any other arrangement. ... [But c] ]ertain parts of the world are undergoing processes of economic integration and disintegration, new experiments are being made.

The debate about common currency arrangements in east Asia has come a long way, even in the past decade. There is a renewed focus on regional integration in trade and investment in east Asia. Under the umbrella of APEC's Bogor declarations of an open trading and investment regime by 2010/20, there have been substantive developments in sub-regional integration and a number of proposals for free trade areas in east Asia. The ASEAN Free Trade Area (AFTA) is now established and the Australia New Zealand Closer Economic Relationship (CER) is well advanced. Proposals for new free trade areas range from mooted bilateral free trade areas - such as between Japan and Korea, Japan and Singapore, and New Zealand and Singapore - to larger free trade areas such as that between AFTA and CER. There is also policy dialogue on economic cooperation between ASEAN, Japan, Korea and China. It makes sense to review longer-term currency arrangements when trade and investment regimes are being substantially liberalised and the structure of economic relations within the region, and between the region and the rest of the world, is changing.

The actual policy debate on common currency arrangements has also changed substantially. A decade ago, commentators noted the reluctance of Japan to take a positive stance towards the formation of a yen bloc in east Asia, partly because of a desire to limit the internationalisation of the yen and partly because of concerns that such a policy may be perceived as a 
second attempt at an Asian co-prosperity area (Frankel 1991; Goto and Hamada 1994). While the Japanese authorities are wary of reawakening historical antagonisms, they are now substantially more relaxed in promoting wide-ranging and public discussion of new financial and currency arrangements in the region (Council on Foreign Exchange and Other Transactions 1999; Sakakibara 1999; Kuroda 2000). In this, they also seem to have some support from within the region, as shown by the public comments in support of an Asian currency unit by HKMA Chief Executive Joseph Yam and Philippines President Joseph Estrada. Consideration of common currency arrangements has been stimulated by the successful introduction of monetary union in Europe, and a concern that the fluctuation of the yen-dollar rate in the 1990s played some part in causing — or at least triggering - east Asia's financial crisis in 1997. Looking at the debate on the issue in Japan, there is also a sense that Japan's prestige as an economic power is on the line unless it becomes the centre of a regional currency arrangement, in the same way as the United States is to the western hemisphere and Germany is to Europe.

The proposals for common currency arrangements are basically of two types. The first is the formation of a currency area, with countries in the region pegging their currencies to a basket of the yen, dollar and euro (Council on Foreign Exchange and Other Transactions 1999; Kuroda 2000). The weights could be based on their own trade shares with Japan, the United States and the European Union. Alternatively, they could be based on a regional average of trade shares with Japan, the United States and the European Union (Dornbusch and Park 1999; Williamson 1999; Murase 2000).

It does not necessarily follow that in a common-basket peg arrangement each country has to adopt a fixed exchange rate or surrender its own monetary sovereignty, although in practice formation of a currency area does limit national policy discretion, and probably to a substantial degree (Kenen 1997; Mussa 1997). Proponents of a common-basket peg argue, for example, that the exchange rate could be fixed to the peg or it could move within a specified band around the peg, say 7-10 per cent (Williamson 1999) or 15 per cent (Murase 2000). This system would also be accompanied by a regional fund to support currencies remaining within the band (Kuroda 2000; Murase 2000), perhaps akin to the reserve credits provided by the European Monetary Cooperation Fund to support the exchange rate pegs of the European Monetary System, established in 1979.

Dornbusch and Park (1999) view a common-basket peg arrangement as the end of the process. Murase (2000), however, sees it only as a first step. He 
argues that the common-basket peg should be converted at some stage to a regional peg, called an Asian currency unit (ACU). This would entail countries in the region pegging their currencies to a weighted average of regional convertible currencies, possibly with some weight given to the dollar and euro but with primary weight given to the yen (see also Sakakibara 1999). The yen would be the de facto anchor currency of the region. A common-basket peg is an important first step because it is seen as a way to increase the correlation of regional currencies with the yen (Council on Foreign Exchange and Other Transactions 1999; Murase 2000). From a non-Japanese perspective, Moon, Rhee and Yoon (2000) and Moon and Rhee (forthcoming 2001) argue for a regional currency unit in preference to a basket peg because they see the former as more likely to engage a wider set of countries in regional currency and liquidity support arrangements, and hence more likely to alleviate fears of domination by Japan. Moon, Rhee and Yoon (2000) envisage a target zone for an ACU maturing into a regional fixed exchange rate system.

For Murase (2000), the final stage is currency union, which is the second type of common currency arrangement. This is admittedly a long-term objective. Interestingly, the proposal for currency union is not that countries in the region formally adopt the yen, but that a new currency be formed. This mimics European monetary union. From Japan's perspective, as Germany was prepared to give up the mark for the euro, so too will Japan give up the yen for a regional currency. This is also more acceptable to non-Japan east Asia (Moon, Rhee and Yoon 2000).

The coverage of the region varies somewhat in the literature. In this paper, the region covers 15 economies, including Australia, Cambodia, China, Hong Kong, Indonesia, Japan, Korea, Laos, Malaysia, New Zealand, the Philippines, Singapore, Thailand, Taiwan and Vietnam. It includes three of the new ASEAN members and, as in the studies of Eichengreen and Bayoumi (1999) and Murase (2000), Australia and New Zealand.

\section{A COMMON-BASKET PEG}

As an alternative to floating or pegging the exchange rate to one major currency, some analysts have recommended that east Asian economies peg their currencies to a basket of the dollar, euro and yen. Williamson (1999), Dornbusch and Park (1999) and Murase (2000) argue, for example, that east Asia - or some subset of it - should collectively peg their currencies to a basket with common trade weights. 
This argument is based on two facts. The first is that over 40 per cent of east Asia's trade is with itself, substantially up from about 20 per cent two decades ago. This fact is used to support the argument that intra-regional exchange rate stability is important for regional economic stability. The second fact is that non-Japan east Asia has substantial trade not just with Japan (about 14 per cent of trade), but also the United States (about 14 per cent) and the European Union (about 12 per cent). This is used to support the argument that east Asian currencies need to be stabilised against a basket of the three major currencies, and not just one of them. ${ }^{2}$

With an emphasis on reducing intra-regional exchange rate volatility, proponents of a basket peg argue that the weights in the basket peg should be the common regional trade shares with Japan, the United States and the European Union. Using a set of common weights eliminates intra-regional exchange rate volatility, whereas using unilateral weights does not.

A basket peg needs to be robust to be viable. In the current environment of open integrated and sophisticated financial markets and large and variable capital flows, it is imperative that exchange rate regimes be sustainable and robust to shocks and speculation. In the first place, countries will only adopt a common-basket peg if it is in their strategic interests to do so. Moreover, it follows that if a regional system of basket pegged exchange rates is or becomes inconsistent with a member country's domestic economic structure or policy regime, it will be tested by speculators, whether they be onshore or offshore.

Table 1 summarises merchandise trade shares for east Asia for 1997. Tables 2 and 3 show merchandise trade intensities for east Asia and the European Union respectively. The trade intensity index is the ratio of the share of a country's exports with another country to the share of that other country in world imports. A number greater than one indicates that a country exports to another country at a greater level than the other is importing from the rest of the world, and a more "intense" bilateral trading relationship. ${ }^{3}$

The general observations made by Bayoumi and Eichengreen (1999) and Williamson (1999) are correct. Almost a half of east Asia's trade is with itself, implying that intra-regional currency stability is important. And

2 To ensure the weights sum to one, the share of trade with the rest of the world is allocated proportionately to these three.

The intensity of trade index for country $i$ to country $j$ is

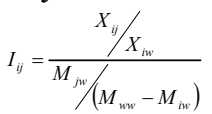

where $X$ is exports $M$ is imports, and subscripts $i, j$ and $w$ indicate country $i$, country $j$ and the world. 
Japan, the United States and the European Union are all important trading partners for east Asia, implying that countries cannot peg to just one major currency if they are to gain stability in the effective exchange rate. Moreover, east Asian trade intensities are mostly above one, and the average intensity for each country in the region is greater than one in all cases, and are highest for Thailand, Singapore and Australia, and lowest for the Philippines, Laos and China. ${ }^{4}$ There are also pockets of particularly high trade intensity in the region, notably between Thailand and Cambodia and Laos, Australia and New Zealand, Hong Kong and China, and Singapore and Malaysia and Cambodia. The average of the trade intensities for east Asia is 2.6, which is higher than the EU-14 average from Table 3 of 1.7..$^{5}$ In addition, the trade intensities of east Asian countries with other countries in the region are generally higher than with the United States or, most especially, the European Union, although the Philippines is an important exception. Bayoumi and Eichengreen (1999) agree with Williamson that, in terms of regional trading patterns, east Asia is as good a candidate for common currency arrangements as western Europe.

Table 1: Merchandise Import, Export and Trade Shares

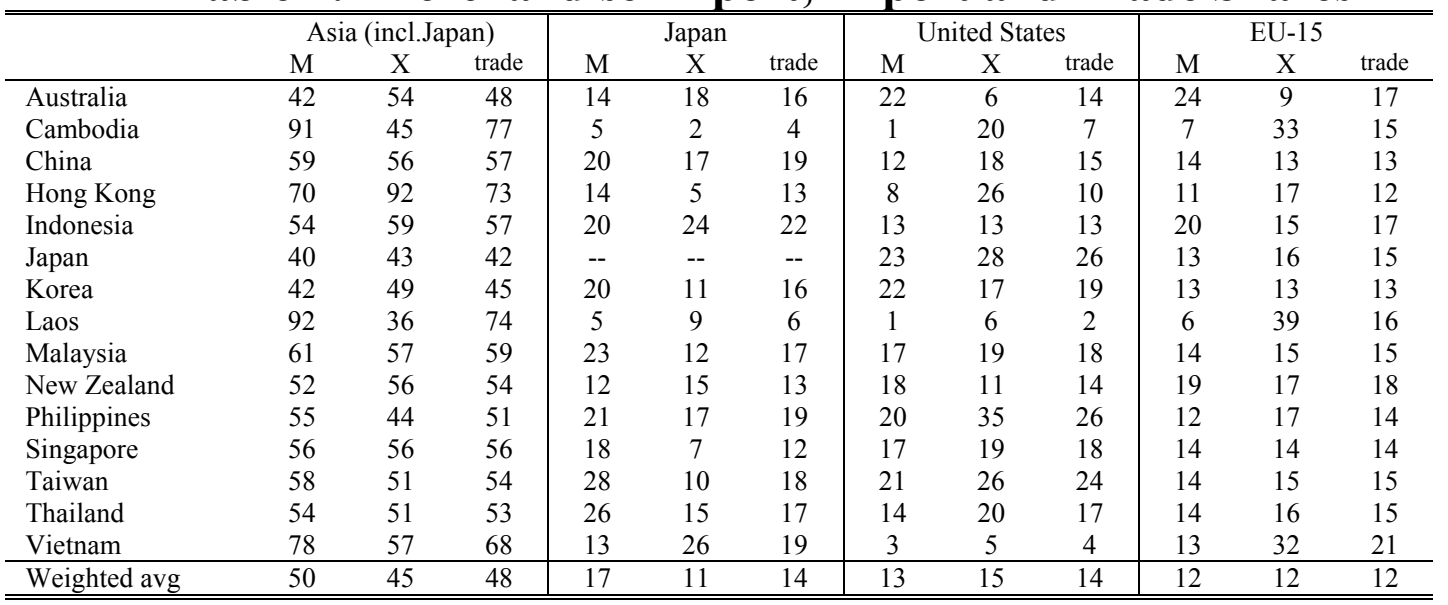

Notes: the weighted average excludes Japan. Trade is the average of exports and imports. The data are from the International Economic Databank (IEDB).

\footnotetext{
The trade intensity is especially high for Thailand because it is a key trading partner for Cambodia and Laos. If these countries are excluded, the average intensity for Thailand falls to 1.8.

This is still the case when the countries with particularly high trade intensities are excluded. If country pairs with trade intensities over 10 are excluded, the average intensity is 1.7 , which is still greater than the average intensity for Europe.
} 
Table 2: Trade Intensity, East Asia, 1995-97

\begin{tabular}{|c|c|c|c|c|c|c|c|c|c|c|c|c|c|c|c|c|c|c|}
\hline & Asia & AUS & $\mathrm{CHN}$ & $\mathrm{HKG}$ & IDN & JPN & KHM & KOR & LAO & MYS & NZL & PHL & SGP & THA & TWN & VNM & USA & $\mathrm{EU}$ \\
\hline AUS & 3.2 & -- & 1.5 & 0.9 & 4.0 & 2.9 & 0.7 & 2.1 & 0.6 & 1.6 & 22.3 & 2.4 & 1.1 & 1.5 & 2.3 & 1.2 & 0.3 & 0.3 \\
\hline $\mathrm{CHN}$ & 1.7 & 0.9 & -- & 5.9 & 1.2 & 2.8 & 1.7 & 1.8 & 2.5 & 0.6 & 0.5 & 1.1 & 0.9 & 0.7 & 1.0 & 2.8 & 1.1 & 0.4 \\
\hline HKG & 1.7 & 0.9 & 10.5 & -- & 0.8 & 0.8 & 1.5 & 0.4 & 0.4 & 0.8 & 0.5 & 1.9 & 1.8 & 0.9 & 1.6 & 1.6 & 1.6 & 0.4 \\
\hline JPN & 1.9 & 1.5 & 1.8 & 1.5 & 2.7 & -- & 0.6 & 2.4 & 0.9 & 2.3 & 1.3 & 2.8 & 1.9 & 3.2 & 3.1 & 1.3 & 1.6 & 0.4 \\
\hline KHM & 2.6 & 0.2 & 2.0 & 1.4 & 0.8 & 0.4 & -- & 0.1 & -- & 2.7 & 0.0 & 0.0 & 5.5 & 17.1 & 0.8 & -- & 0.7 & 1.3 \\
\hline KOR & 2.0 & 1.2 & 3.3 & 2.0 & 3.1 & 1.9 & 0.6 & -- & 0.5 & 1.8 & 0.6 & 2.4 & 1.6 & 1.5 & 1.5 & 6.2 & 1.1 & 0.3 \\
\hline NZL & 2.4 & 16.4 & 1.0 & 0.8 & 2.0 & 2.4 & 0.4 & 1.9 & 0.1 & 1.6 & -- & 2.0 & 0.6 & 1.1 & 1.5 & 1.4 & 0.6 & 0.4 \\
\hline PHL & 1.3 & 0.7 & 0.5 & 1.2 & 0.8 & 2.7 & 0.3 & 0.9 & 0.1 & 1.9 & 0.4 & -- & 2.4 & 2.8 & 2.0 & 1.8 & 2.3 & 0.5 \\
\hline SGP & 4.4 & 1.9 & 1.0 & 2.3 & -- & 1.2 & 16.7 & 1.1 & 3.9 & 12.1 & 1.1 & 2.9 & -- & 4.2 & 2.1 & 7.2 & 1.1 & 0.4 \\
\hline THA & 6.9 & 1.3 & 1.2 & 1.4 & 2.3 & 2.6 & 16.3 & 0.7 & 53.8 & 2.7 & 0.7 & 1.6 & 5.1 & -- & 1.4 & 3.1 & 1.2 & 0.4 \\
\hline TWN & 1.8 & 1.3 & 1.8 & 4.9 & 1.8 & 1.7 & 1.0 & 0.8 & 0.3 & 1.8 & 0.9 & 2.4 & 1.6 & 2.0 & -- & 3.1 & 1.5 & 0.4 \\
\hline
\end{tabular}

Notes: the Asia trade intensity is the unweighted average of trade intensities with the rest of east Asia. The data are from the International Economic Databank (IEDB).

Table 3: Trade Intensity, European Union, 1995-97

\begin{tabular}{|c|c|c|c|c|c|c|c|c|c|c|c|c|c|c|c|c|}
\hline & EU14 & AUT & BLX & DEU & DNK & ESP & FIN & FRA & GBR & GRC & IRL & ITA & NLD & PRT & SWE & USA \\
\hline$\overline{\text { AUT }}$ & 1.2 & -- & 0.5 & 4.2 & 0.9 & 0.9 & 0.9 & 0.7 & 0.6 & 1.0 & 0.3 & 2.4 & 0.9 & 0.6 & 1.0 & 0.2 \\
\hline BLX & 1.6 & 0.8 & -- & 2.2 & 1.0 & 1.2 & 0.9 & 3.2 & 1.6 & 1.2 & 0.6 & 1.4 & 4.0 & 1.1 & 1.1 & 0.3 \\
\hline DEUX & 1.8 & 3.9 & 1.8 & -- & 2.0 & 1.4 & 1.4 & 1.9 & 1.4 & 1.4 & 0.6 & 1.9 & 2.1 & 1.4 & 1.7 & 0.4 \\
\hline DNK & 1.9 & 0.7 & 0.6 & 2.3 & -- & 0.8 & 4.2 & 0.9 & 1.5 & 1.5 & 0.8 & 1.0 & 1.3 & 0.8 & 8.1 & 0.2 \\
\hline ESP & 2.4 & 0.6 & 1.0 & 1.6 & 0.8 & -- & 0.6 & 3.7 & 1.5 & 2.1 & 0.6 & 2.6 & 1.1 & 13.7 & 0.7 & 0.3 \\
\hline FIN & 1.8 & 0.7 & 0.8 & 1.4 & 3.6 & 1.0 & -- & 0.8 & 1.8 & 1.2 & 0.9 & 0.8 & 1.3 & 0.8 & 8.1 & 0.5 \\
\hline FRA & 1.7 & 0.8 & 2.6 & 1.9 & 1.0 & 3.2 & 0.7 & -- & 1.7 & 1.7 & 0.8 & 2.6 & 1.4 & 2.1 & 1.1 & 0.4 \\
\hline GBR & 1.9 & 0.5 & 1.5 & 1.3 & 1.4 & 1.5 & 1.6 & 1.7 & -- & 1.3 & 7.4 & 1.2 & 2.3 & 1.5 & 1.9 & 0.7 \\
\hline GRC & 1.2 & 1.2 & 0.7 & 2.5 & 0.9 & 1.5 & 1.2 & 1.1 & 1.2 & -- & 0.4 & 2.9 & 0.9 & 0.6 & 1.1 & 0.3 \\
\hline IRL & 1.5 & 0.4 & 1.6 & 1.5 & 1.5 & 1.1 & 1.0 & 1.7 & 4.6 & 1.1 & -- & 1.0 & 2.3 & 0.7 & 1.4 & 0.6 \\
\hline ITA & 1.5 & 2.0 & 1.0 & 2.0 & 1.0 & 2.2 & 0.9 & 2.4 & 1.2 & 3.1 & 0.5 & -- & 0.9 & 1.4 & 0.8 & 0.5 \\
\hline NLD & 1.8 & 1.1 & 3.8 & 2.9 & 1.9 & 1.2 & 1.5 & 1.9 & 1.6 & 2.3 & 1.3 & 1.5 & -- & 1.3 & 1.8 & 0.2 \\
\hline PRT & 2.0 & 1.1 & 1.3 & 2.5 & 2.4 & 6.7 & 1.5 & 2.8 & 2.1 & 0.6 & 0.7 & 0.7 & 1.6 & -- & 1.8 & 0.3 \\
\hline SWE & 2.2 & 0.8 & 1.4 & 1.3 & 7.2 & 0.9 & 8.5 & 0.9 & 1.7 & 1.0 & 0.9 & 1.0 & 1.8 & 0.8 & -- & 0.5 \\
\hline USA & 0.4 & 0.2 & 0.6 & 0.4 & 0.3 & 0.3 & 0.4 & 0.4 & 0.8 & 0.3 & 0.8 & 0.4 & 0.8 & 0.2 & 0.4 & -- \\
\hline
\end{tabular}

Notes: the EU14 trade intensity is the unweighted average of trade intensities with the rest of the EU14. The data are from the International Economic Databank (IEDB).

It is not clear, however, that the weights in a peg should be based on trade shares. If the authorities target the exchange rate for the purpose of stabilising trade, then it is the exchange rate elasticities of imports and exports that matter rather than simple trade shares (Turnovsky 1982), possibly also taking into account different structures in firms and markets (Ito, Ogawa and Sasaki 1998). ${ }^{6}$ The problem with constructing basket pegs this way is that estimates of trade elasticities are highly imprecise - see, for example, the wide range of estimates in Ito, Ogawa and Sasaki (1998) - and there is no consensus on the "right" numbers.

It is also not clear that the objective function of stabilising the trade balance is the best one for policymakers: the trade balance is endogenous and

Using a micro model, they argue that the optimal weights in a currency peg depend on the degree of market power of firms in product and input markets, the degree of import penetration of production, and the currency denomination of product and input markets. 
insulates the real economy from a variety of domestic and foreign shocks, with the optimal policy usually being to let the trade account widen or narrow, depending on the type and duration of the shock. The widening of the US current account deficit during the east Asian financial crisis, for example, was an important stabilising mechanism in both the east Asian and the US economies.

Others argue that the weights in a basket peg should be constructed with the aim of stabilising output, and hence weights should be biased to the currencies of key similar economies that are less likely to be subject to major shocks (Argy, McKibbin and Siegloff 1989; Yoshino, Koji and Suzuki 2000). The problem with constructing basket pegs this way is that there is no consensus on the "right" model.

Even if countries target a peg based on trade weights, it is not clear that common weights would suit the region. If a country is to target a basket of currencies, it may do better to target a basket peg based on its own, rather than common, trade weights. This argument has two strands. The first is that trade patterns vary sufficiently between some countries in east Asia as to disadvantage them relative to their peers under a common-basket peg when the yen or euro fluctuates against the US dollar. The second is that a common peg implicitly assumes that reducing intra-regional exchange rate variability is more important than reducing exchange rate variability between east Asia and its main export markets of Japan, the United States and the European Union. Consider these two issues in turn.

\section{Divergent trade weights}

The first three columns of Table 4 set out currency basket weights for east Asia with respect to the yen, dollar and euro that are proportional to the trade shares with Japan, the United States and the European Union shown in Table 1. In this case, the rounded currency weights for the region as a whole are 0.35 for Japan, 0.35 for the United States and 0.30 for the European Union. These are very similar to the currency weights proposed by Williamson (1999).

There is, however, substantial variation around this average (see also Pisani-Ferry 1999). It is most striking in the case of the new ASEAN members, Cambodia, Laos and Vietnam. ${ }^{7}$ Trade patterns for these countries are highly skewed to other countries in the region, especially Thailand and Singapore. They have little trade with the United States, but

Burma is not examined in this paper since it is even less integrated than Laos. 
the European Union accounts for about a third of their exports. Vietnam is the only one of the three to have any significant sort of trading relationship with Japan. The fact that the Indochinese countries are such outliers and that they are less well economically developed has meant that they have been excluded from analysis of common currency arrangements in east Asia. Since 1999, however, they have been part of ASEAN and, given ASEAN's desire to be treated as a grouping, they cannot simply be ignored.

It is not just Indochina which is an outlier in the region; there are also substantial differences between particular countries. Indonesia and Singapore are two good cases in point. On the one hand, 22 per cent of Indonesia's trade is with Japan and only 13 per cent is with the United States. On the other hand, 18 per cent of Singapore's trade is with the United States and only 12 per cent is with Japan. A common-basket peg with the weights outlined above would be less stabilising than a basket with each country's own weights. Consider, for example, a generalised 10 per cent depreciation of the yen. To keep the common-basket-weight nominal effective exchange rate constant, each country's currency would need to depreciate by about 5.4 per cent against the US dollar and euro. Since regional currencies have moved by the same amount, intra-regional exchange rates would be unchanged.

Table 4: G-3 Currency Weights and Exchange Rate Effects

\begin{tabular}{|c|c|c|c|c|c|c|c|}
\hline & \multirow{2}{*}{\multicolumn{3}{|c|}{ Trade-based G-3 currency weights }} & \multicolumn{4}{|c|}{ Common regional G-3 trade basket peg } \\
\hline & & & & \multicolumn{2}{|c|}{$\begin{array}{c}\text { yen depreciates } 10 \% \\
\text { (and local currency } \\
\text { depreciates } 5.4 \% \text { against the } \\
\text { dollar and euro) }\end{array}$} & \multicolumn{2}{|c|}{$\begin{array}{c}\text { euro depreciates } 10 \% \\
\text { (and local currency } \\
\text { depreciates } 4.3 \% \text { against the } \\
\text { dollar and yen) }\end{array}$} \\
\hline & Yen & US Dollar & Euro & $\begin{array}{c}\text { Divergence } \\
\text { from own } \\
\text { G-3 trade } \\
\text { basket peg }\end{array}$ & $\begin{array}{l}\text { Loss }(+) \text { of } \\
\text { competitive- } \\
\text { ness to rest of } \\
\text { Asia }\end{array}$ & $\begin{array}{c}\text { Divergence } \\
\text { from own } \\
\text { G-3 trade } \\
\text { basket peg }\end{array}$ & $\begin{array}{c}\text { Loss }(+) \text { of } \\
\text { competitive- } \\
\text { ness to rest of } \\
\text { Asia }\end{array}$ \\
\hline Australia & 34 & 30 & 36 & -0.2 & -0.3 & 0.9 & 1.0 \\
\hline Cambodia & 15 & 27 & 57 & -3.0 & -3.1 & 3.9 & 4.0 \\
\hline China & 40 & 32 & 28 & 0.7 & 0.7 & -0.3 & -0.1 \\
\hline Hong Kong & 37 & 29 & 34 & 0.3 & 0.6 & 0.6 & 0.4 \\
\hline Indonesia & 42 & 25 & 33 & 1.0 & 0.7 & 0.4 & 0.5 \\
\hline Korea & 33 & 40 & 27 & -0.3 & -0.1 & -0.4 & -0.3 \\
\hline Laos & 26 & 9 & 65 & -1.4 & -0.9 & 5.0 & 4.9 \\
\hline Malaysia & 35 & 36 & 29 & 0.0 & -0.4 & -0.1 & -0.1 \\
\hline New Zealand & 29 & 31 & 39 & -0.9 & -1.0 & 1.3 & 1.7 \\
\hline Philippines & 32 & 44 & 24 & -0.4 & -0.5 & -0.9 & -0.8 \\
\hline Singapore & 28 & 40 & 32 & -1.1 & -0.9 & 0.3 & 0.3 \\
\hline Taiwan & 31 & 43 & 26 & -0.5 & -0.4 & -0.6 & -0.5 \\
\hline Thailand & 39 & 32 & 28 & 0.7 & 0.5 & -0.2 & -0.1 \\
\hline Vietnam & 43 & 9 & 49 & 1.2 & 1.1 & 2.7 & 2.7 \\
\hline Weighted avg & 35 & 35 & 30 & & & & \\
\hline
\end{tabular}

Notes: competitiveness for each country is estimated as the sum of the divergences weighted by trade share with that country. 
But countries' relative competitiveness has altered (Pisani-Ferry 1999). If Indonesia seeks to keep its own effective exchange rate constant in the face of its 10 per cent appreciation against the yen, then, since Japan is such a large trading partner, it needs to depreciate by 7.2 per cent against the dollar and euro. By only depreciating 5.4 per cent against them, its own effective exchange rate appreciates by 1 percent. Because Singapore trades more with the United States, however, its own effective exchange rate depreciates by 1.1 per cent if the Singapore dollar depreciates 5.4 per cent against the dollar and euro. It would only need to depreciate 3.9 per cent, not 5.4 per cent, against the dollar and euro to keep its own effective exchange rate unchanged. If both countries target a commonbasket peg, then in this particular case Indonesia suffers a loss of competitiveness against Singapore of over 2 per cent. This matters because Indonesia and Singapore are important trading partners (Table 2).

The issue is shown more generally in the last four columns of Table 4, which set out the differences in exchange rates and relative competitiveness between common and own basket weights for a 10 per cent depreciation in the yen or the euro. In both cases, the home currency depreciates against the US dollar and other major currency (euro and yen respectively) to keep the effective exchange rate unchanged. Column 4 shows the difference in the effective exchange rate when the country targets a common-basket peg rather than its own basket for depreciation of the yen. The divergence in the effective exchange rate is greatest for Indochinese countries. The sign also varies between countries. Column 5 shows the effect on competitiveness with the rest of the region in this case. Wedges in competitiveness arise between countries which trade relatively more with Japan, like China, Hong Kong and Indonesia, and those which trade relatively more with the United States, like the Philippines, Singapore and Taiwan. In terms of movements in the euro, wedges in competitiveness arise between countries which trade relatively more with the EU, like Australia, Hong Kong, Indonesia and New Zealand, and those which trade relatively more with the United States, like Korea, the Philippines and Taiwan (Columns 6 and 7). Depending on which major currency moves, some countries in the region will be disadvantaged under a common-basket peg.

\section{Export similarity}

The other reason why it may not be in a country's interests to peg its currency to a basket with common weights is that a common-basket peg implicitly assumes that reducing intra-regional exchange rate variability is 
more important than reducing exchange rate variability with some of the world's largest exporters, Japan, the United States and the European Union. Williamson (1999) uses 1992 trade data to argue that east Asia's intraregional exports are more similar than those of east Asia with Japan, the United States and Europe. ${ }^{8}$ This warrants some scrutiny, and Table 5 shows the export similarity index for east Asia estimated using annual merchandise export data, averaged over 1995 to 1997, to the 3-digit SITC level. The numbers range between 0 and 1 .

On the evidence provided by these data, it is no longer possible to accept Williamson's assessment that exports in non-Japan east Asia are more similar than the region's exports to Japan, the United States and the European Union, and hence that intra-regional exchange rate stability is more important for maintaining export competitiveness than stability against the yen, dollar or euro.

\section{Table 5: Export Similarity Index for Total Merchandise Trade, 95-97}

\begin{tabular}{|c|c|c|c|c|c|c|c|c|c|c|c|c|c|c|c|c|c|c|}
\hline & Aus & Cam & Chn & HK & Idn & Kor & Laos & Mys & $\mathrm{NZ}$ & $\mathrm{Phl}$ & Sgp & Twn & Thl & Vnm & Jpn & US & EU & Asia \\
\hline Aus & -- & 0.27 & 0.24 & 0.30 & 0.21 & 0.16 & 0.27 & 0.15 & 0.30 & 0.21 & 0.26 & 0.17 & 0.20 & 0.16 & 0.16 & 0.28 & 0.32 & 0.22 \\
\hline Cam & & -- & 0.30 & 0.49 & 0.33 & 0.09 & 0.74 & 0.17 & 0.24 & 0.24 & 0.09 & 0.11 & 0.25 & 0.31 & 0.04 & 0.12 & 0.13 & 0.28 \\
\hline Chn & & & -- & 0.43 & 0.50 & 0.40 & 0.35 & 0.37 & 0.21 & 0.49 & 0.39 & 0.49 & 0.58 & 0.48 & 0.35 & 0.45 & 0.49 & 0.40 \\
\hline HK & & & & -- & 0.34 & 0.26 & 0.49 & 0.30 & 0.14 & 0.41 & 0.32 & 0.32 & 0.45 & 0.35 & 0.28 & 0.34 & 0.30 & 0.36 \\
\hline Idn & & & & & -- & 0.29 & 0.39 & 0.40 & 0.15 & 0.46 & 0.29 & 0.33 & 0.49 & 0.46 & 0.20 & 0.32 & 0.34 & 0.36 \\
\hline Kor & & & & & & -- & 0.11 & 0.43 & 0.18 & 0.35 & 0.48 & 0.54 & 0.38 & 0.23 & 0.66 & 0.51 & 0.46 & 0.30 \\
\hline Laos & & & & & & & -- & 0.16 & 0.35 & 0.30 & 0.12 & 0.15 & 0.30 & 0.47 & 0.07 & 0.17 & 0.20 & 0.32 \\
\hline Mys & & & & & & & & -- & 0.13 & 0.53 & 0.62 & 0.46 & 0.47 & 0.21 & 0.40 & 0.41 & 0.37 & 0.34 \\
\hline $\mathrm{NZ}$ & & & & & & & & & -- & 0.13 & 0.18 & 0.13 & 0.21 & 0.21 & 0.14 & 0.23 & 0.25 & 0.20 \\
\hline $\mathrm{Phl}$ & & & & & & & & & & -- & 0.45 & 0.45 & 0.54 & 0.37 & 0.33 & 0.36 & 0.31 & 0.38 \\
\hline Sgp & & & & & & & & & & & -- & 0.63 & 0.46 & 0.19 & 0.47 & 0.50 & 0.50 & 0.34 \\
\hline Twn & & & & & & & & & & & & -- & 0.48 & 0.25 & 0.47 & 0.48 & 0.47 & 0.35 \\
\hline Thl & & & & & & & & & & & & & -- & 0.46 & 0.36 & 0.46 & 0.46 & 0.41 \\
\hline Vnm & & & & & & & & & & & & & & -- & 0.15 & 0.21 & 0.25 & 0.32 \\
\hline
\end{tabular}

Notes: the Asia figure is an unweighted average and excludes Japan. The data are from the International Economic Databank (IEDB).

For Australia, China, Korea, New Zealand, Singapore and Taiwan, Japan, the United States and/or the European Union are among the four most similar export markets. In all of these cases bar Korea, the export

$8 \quad$ The export similarity index was devised by Finger and Kreinen (1979). It may be written as:

$$
S_{a b}=1-\frac{1}{2} \sum_{i}\left|\frac{X_{a}^{i}}{X_{a}}-\frac{X_{b}^{i}}{X_{b}}\right|
$$

where $X_{a}^{i}$ is country $a$ 's exports of commodity $i$ to the rest of the world and $X_{a}$ is country $a$ 's total exports to the rest of the world.. 
similarity is with the United States or the European Union, not Japan. ${ }^{9}$ Moreover, the exports of Australia, China, Korea, Malaysia, New Zealand, Singapore, Taiwan and Thailand are more similar, on average, to those of Japan, the United States and the European Union, than to the exports of the rest of non-Japan east Asia. The countries which have exports that are least similar to those of the major industrialised countries are the less developed economies, like Indonesia and the Philippines, and Cambodia, Laos and Vietnam.

The exports of the more industrialised countries in the region (that is, Australia, China, Korea, Malaysia, New Zealand, Singapore, Taiwan and Thailand) account for about 15 per cent of world exports. The major industrialised countries with whose exports they compete account for 57 per cent of world exports. It matters that the more industrialised countries in the region remain competitive in world markets.

The structure of export similarity in the region has changed substantially in the past decade. In 1988-1990, only Australia included the United States in the list of the top four countries with export structures most similar to its. For the region as whole, the average similarity of exports with those of the United States has risen from 0.31 in 1988-90 to 0.37 in 1995-97, with the rise greatest for Thailand ( 0.24 to 0.46 ), Korea (0.34 to 0.46$)$, Malaysia ( 0.27 to 0.37$)$ and Taiwan (0.39 to 0.47$)$. Intra-regional trade may be becoming more important, but the region's export structure is also becoming more similar to that of the industrialised countries of the world, not less. Williamson is right that the rest of region is an important competitor to east Asian countries, but it is not necessarily the most important. His argument that non-Japan east Asia intra-regional trade is more similar than extra-regional trade only appears now to apply to the less developed economies in the region.

There are also a number of other, more general factors which are relevant in assessing whether east Asia would be better off adopting a commonbasket exchange rate peg.

\footnotetext{
This has an important implication. Based on a 3-country intertemporal model, Argy, McKibbin and Siegloff (1989) conclude that the weights in a currency basket should be biased towards the currency of the economy that is more likely to be subject to fewer and smaller shocks, rather than on trade shares. To the extent that export similarity indicates that economic structures are similar, the dollar and euro should have higher weights than the yen in a basket peg.
} 


\section{Initial conditions}

First, starting points matter. While many countries in the region largely targeted the US dollar exchange rate before the financial crisis, many of these countries shifted to independently floating exchange rate regimes during the crisis. Malaysia is the key exception, fixing its exchange rate in September 1998, while Indonesia, Korea, the Philippines and Thailand have now floated their currencies (Table 6). This seems to be part of a more general phenomenon (Obstfeld and Rogoff 1995; Eichengreen et al. 1999; Mussa et al. 2000). The case for a common basket, therefore, has to be made against the current alternative - floating exchange rates - and not what countries did a few years ago.

Table 6: Currency Arrangements in East Asia

\begin{tabular}{lccc}
\hline \hline & 1980 & 1990 & 2000 \\
\hline Australia & crawling peg & independently floating & independently floating \\
Cambodia & n/a & composite peg & composite peg \\
China & n/a & composite peg & managed float \\
Hong Kong & float & US dollar peg & US dollar peg \\
Indonesia & managed float & managed float & independently floating \\
Japan & independently floating & independently floating & independently floating \\
Korea & managed float & managed float & independently floating \\
Laos & US dollar peg & US dollar peg & US dollar peg \\
Malaysia & composite peg & managed float & US dollar peg \\
New Zealand & crawling peg & independently floating & independently floating \\
Philippines & managed float & independently floating & independently floating \\
Singapore & composite peg & composite peg & composite peg \\
Taiwan & managed float & managed float & independently floating \\
Thailand & composite peg & composite peg & independently floating \\
Vietnam & composite peg & composite peg & composite peg \\
\hline \hline
\end{tabular}

Notes: sources are the IMF's Exchange Arrangements and Exchange Restrictions Annual Report, various, and author's assessment.

Williamson (1999) and Murase (2000) argue that this does not matter, since their proposals for a common-basket peg also allow for countries to target the peg around a band, up to plus/minus 15 per cent, if they prefer. This is difficult to accept. In the first place, to the extent that countries target a peg but let their exchange rates move around it in a very wide band, the proposal simply lacks content. The idea that countries can in practice retain substantial domestic policy autonomy (including over the exchange rate) when they adopt even a limited peg is not supported in the literature (Kenen 1997; Mussa 1997). Even if countries do not fix tightly to a peg, they tend to be substantially constrained in how much currency movement around it they can accommodate. A putative shift to a common-basket peg may mean substantial change to the exchange rate regime. It is not surprising, then, that Frenkel and Goldstein (1986) refer to a target peg as a hybrid floating-fixed exchange rate regime. 
Having shifted to a floating exchange rate, why should countries shift back to a system of fixed parities, especially when this was part of the problem in the first place? Ogawa and Ito (2000:5) argue that a floating exchange rate regime will not protect countries from contagion and are not viable since "the worst of the Asian crisis, say November 1997 to January 1998, came long after the Asian economies moved to a flexible exchange rate regime". While it is foolish to argue that a floating regime is a panacea, their criticism is overstated. In the first place, Korea did not float until much later, in December 1997. In the cases of Indonesia, Malaysia and Thailand, the exchange rate regime may have become more flexible in the latter part of 1997, but many of the problems that existed were the product of the fixed exchange rate regime, namely the implicit guarantee that substantial devaluation would not occur and the effect this had on economic decision making.

Exchange rate realignments occur under both regimes. The advantage of a floating-rate regime is that decision-makers learn how to cope with this risk. The origin of the recent crisis lay, in part, in the combination of relatively high local interest rates, semi-fixed exchange rate regimes and limits on long-term capital flows (like FDI). This provided a powerful incentive for local firms to borrow short-term and unhedged in foreign currencies, and left them exceptionally vulnerable to movements in the exchange rate (Alba, Bhattacharya, Claessons, Ghosh and Hernandez 1999). This lesson has been learnt. Individuals, businesses and governments now know that foreign exchange markets can be volatile, they will modify their actions accordingly and hence reduce the vulnerabilities to the economy from exchange rate variability. ${ }^{10}$ All else given, the need to shift to a pegged regime is less when decision-makers have started to learn to deal with flexible and variable exchange rates.

\footnotetext{
10 Australia's experience in the mid 1980s is relevant. Australia removed capital controls and floated its currency in December 1983. It had also fully deregulated its financial system by the mid 1980s. Liberalisation and deregulation created major challenges for risk management by banks, firms and households. In the first instance, in the mid 1980s, encouraged by some local banks, some firms and households took low interest Swiss franc loans without taking forward cover. Subsequently, the Australian dollar depreciated by about 30 per cent, in response to deteriorating terms of trade, and their Australian dollar interest costs rose substantially. Similarly, a number of manufacturing, energy and other firms took open speculative positions in foreign exchange, and subsequently recorded substantial losses. These experiences had a cathartic effect on managing foreign exchange rate risk in Australia. Firms typically make extensive use of hedging instruments, and non-financial firms place particular attention to limits and internal governance processes with respect to financial activities. Commercial banks in Australia are also risk averse in managing foreign exchange risks and do not hold large open positions (de Brouwer 1999).
} 


\section{Exchange rate volatility and trade}

An underlying argument for a common-basket peg is that exchange rate volatility creates uncertainty and adversely affects trade and economic performance. The evidence that currency volatility adversely affects trade is mixed and inconclusive, with some studies even showing that exchange rate volatility stimulates trade perhaps because it gives firms the opportunity to buy imports at low prices and sell exports at high prices (Gagnon 1993; Isard 1995; Wei 1999). In any event, the argument is not persuasive without evidence that currency variability adversely affects trade. For east Asia this may be hard to show since intra-regional trade increased in the 1990s despite relatively volatile currency markets.

Figure 1 plots intra-regional exports in non-Japan east Asia in real US dollars (1995 prices) and a measure of intra-regional exchange rate variability. ${ }^{11}$ Intra-regional exports have increased progressively from US $\$ 41$ billion in 1980 to US\$368 billion in 1997, against a backdrop of periods of substantial regional currency variability. As evident from Figure 2, changes in real intra-regional exports and exchange rate variability are positively correlated - the contemporaneous correlation is 0.15 and the correlation of the change in intra-regional trade and exchange rate volatility in the previous is 0.29 .

The evidence that currency volatility adversely affects economic performance overall is also mixed. On the one hand, while it is exceedingly obvious that the currency volatility associated with the east Asian financial crisis was costly, it is important to remember that the crisis was largely initiated in economies with fixed exchange rates. On the other hand, flexible exchange rates enable financial markets to provide a powerful discipline on public and private policymakers to implement policies which support stable non-inflationary economic growth. They also provide governments with an excuse or shield behind which they can implement unpopular but "good" policies.

\footnotetext{
11 Intra-regional exchange rate variability is estimated as the weighted sum of each country's annual exchange volatility, where the weight is the country's share in regional exports. Each country's annual exchange volatility is the weighted sum of the annual standard deviation of changes in its endmonth bilateral exchange rate against each country in the region, where the weight is the share in the country's exports. Weights are estimated using 1997 trade data.
} 
Figure 1: Intra-regional Exchange Rate Volatility and Exports

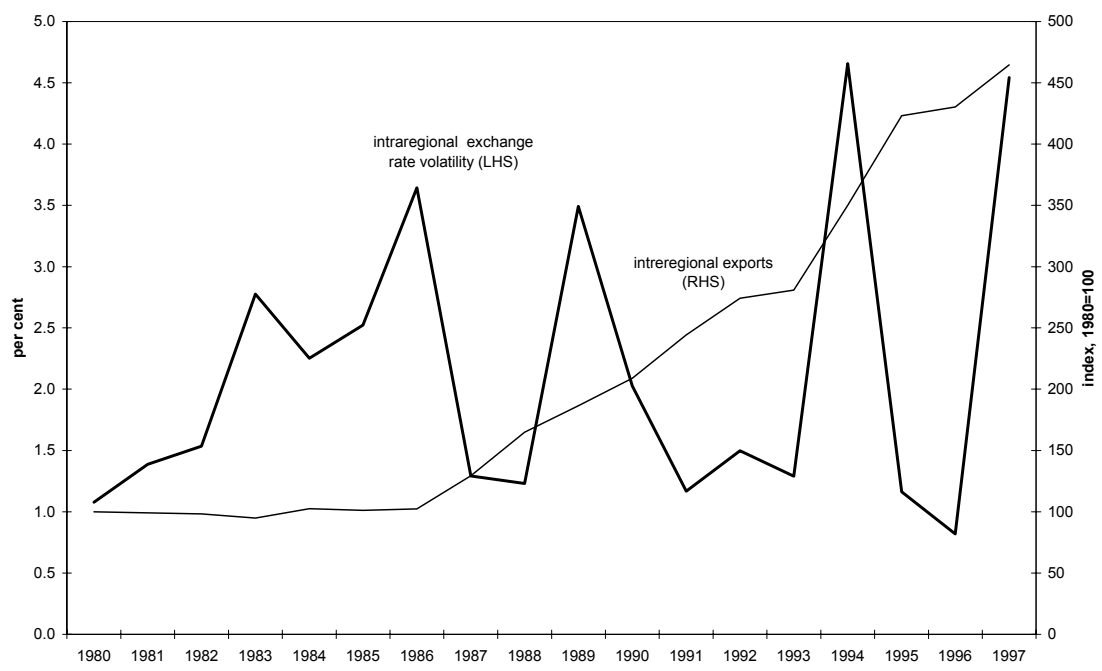

Figure 2: Intra-regional Exchange Rate Volatility and Change in East Asian Exports

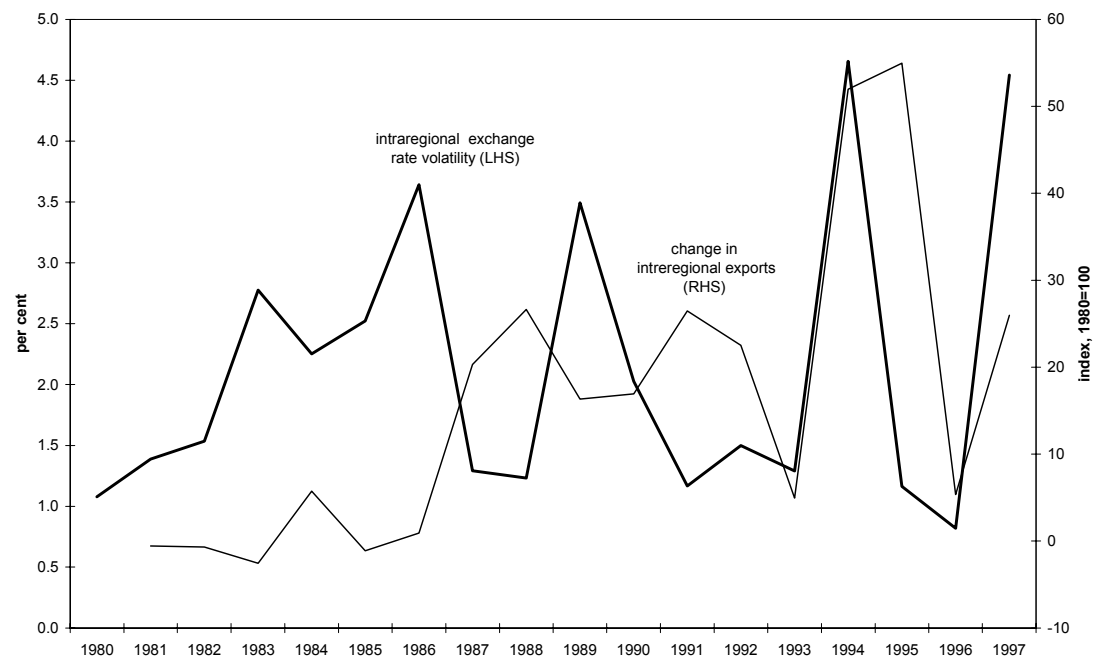

\section{Real exchange rate adjustment}

To the extent that pegging to a common basket entails a loss of flexibility in the nominal exchange rate, countries that peg are in fact shifting adjustment of the real exchange rate to domestic inflation from the nominal exchange rate. This may be costly since changes in the nominal exchange rate can be an efficient way to generate movements in the real exchange rate, particularly when domestic inflation is relatively persistent.

Movements in the real exchange rate are an important mechanism for achieving internal and external balance in an economy, and they will occur irrespective of the nominal exchange rate regime, although the speed and 
structure of adjustment will vary depending on whether it occurs through the nominal exchange rate or domestic inflation (Dornbusch 1976; Mussa 1980; Dornbusch and Park 1999). In a fixed exchange rate regime, the burden of adjustment in the real exchange rate falls on the relative inflation rate rather than the nominal exchange rate. For example, a fixed exchange rate economy which needs a boost to competitiveness can only achieve a real depreciation through a lower inflation rate. The less flexible are domestic prices and wages and the greater the persistence in inflation, the bigger is the output gap needed to reduce inflation. The cost of relying on inflation to generate real exchange rate adjustments is increased if high or variable inflation is itself costly to economic efficiency. Forcing adjustment of the real exchange rate to inflation is likely to be incompatible with using an inflation target as the nominal anchor for monetary policy.

Table 7: Inflation and Exchange Rates in East Asia Autocorrelation and Nominal and Real Depreciation (minus sign indicates depreciation, positive sign indicates appreciation)

\begin{tabular}{|c|c|c|c|c|c|c|c|c|}
\hline & \multirow{2}{*}{\multicolumn{2}{|c|}{$\begin{array}{c}\text { Autocorrelation } \\
1995-99\end{array}$}} & \multicolumn{6}{|c|}{ Exchange rate depreciation } \\
\hline & & & \multicolumn{2}{|c|}{$1990-96$} & \multicolumn{2}{|c|}{ 1997-99 } & \multicolumn{2}{|c|}{ 1990-99 } \\
\hline & Inflation & $\begin{array}{l}\text { Exchange } \\
\text { rate change }\end{array}$ & Nominal & Real & Nominal & Real & Nominal & Real \\
\hline Australia & 0.71 & 0.10 & 0.5 & -3.1 & -17.9 & -19.0 & -17.5 & -21.6 \\
\hline Hong Kong & 0.30 & -0.30 & 0.9 & 45.7 & -0.5 & -6.9 & 0.5 & 35.6 \\
\hline Indonesia & 0.74 & 0.03 & -24.7 & 1.2 & -66.4 & -36.9 & -74.7 & -36.2 \\
\hline Japan & 0.21 & 0.08 & 23.6 & 7.3 & 13.6 & 8.3 & 40.5 & 16.3 \\
\hline Korea & 0.44 & 0.16 & -19.5 & -2.1 & -26.3 & -21.4 & -40.7 & -23.1 \\
\hline Malaysia & 0.13 & 0.10 & 6.8 & 8.5 & -33.5 & -30.5 & -29.0 & -24.6 \\
\hline New Zealand & 0.29 & 0.00 & 19.2 & 13.3 & -26.4 & -29.1 & -12.2 & -19.7 \\
\hline Philippines & 0.12 & 0.20 & -14.6 & 30.0 & -34.8 & -25.0 & -44.3 & -2.5 \\
\hline Singapore & 0.06 & 0.09 & 35.3 & 26.2 & -16.0 & -19.5 & 13.7 & 1.6 \\
\hline Taiwan & -0.21 & 0.05 & -4.8 & -2.7 & -12.4 & -15.5 & -16.7 & -17.8 \\
\hline Thailand & 0.36 & 0.13 & 0.7 & 12.2 & -33.1 & -28.8 & -32.6 & -20.1 \\
\hline
\end{tabular}

Notes: autocorrelations are monthly except for the Australian and New Zealand consumer price indices; depreciation is relative to the US dollar; real exchange rate is calculated using the CPI.

As shown in the first two columns of Table 7, inflation generally seems to be more persistent than changes in the exchange rate in east Asia, although the Philippines and Singapore appear to be the main exceptions to this generalisation. Changes in the real exchange rate seem to be effected through changes in the nominal exchange rate in countries in the region which have floating exchange rates (Australia, New Zealand and Singapore), and through the domestic inflation rate in countries with fixed exchange rates (Hong Kong). The substantial nominal depreciations experienced in recent years in non-Japan east Asia have uniformly been largely converted to real depreciations as well. To the extent that a basket 
peg involves fixing the exchange rate, one apparently effective tool may be lost in generating real exchange rate flexibility.

\section{Common Economic Structure and Policies}

It is well known that the robustness of any common exchange rate policy, including a common-basket peg, depends on how similar are the economies and policies of the members (Mundell 1961). To the extent that economic structures and policies differ between countries participating in the peg, the exchange rate will be less supportive of economic adjustment in particular countries. Moreover, the more different economic structures and policies are among participating countries, the more likely are realignments to be necessary as external conditions change.

Goto and Hamada (1994) examine and estimate principal components for a range of macroeconomic and trade variables in east Asia. They find a relatively high degree of synchronisation between shocks for the region, and conclude that the "degree of interdependence among Asian nations is high, even higher in some respects than among EC countries" (page 354). Eichengreen and Bayoumi (1999) use a Blanchard-Quah decomposition on east Asian output and prices to identify supply and demand shocks. They find that supply shocks are correlated for different sets of countries in the region. They also examine historical influences in economic integration in east Asia, and conclude that political and institutional cohesion remains weak. Bayoumi and Mauro (1999) and Bayoumi, Eichengreen and Mauro (2000) examine whether ASEAN is an optimal currency area, and reach conclusions similar to Eichengreen and Bayoumi (1999).

One way to identify the need for realignments of the nominal exchange rate is to see whether countries' real effective exchange rates in the region move together. Real effective exchange rates are the outcome of the interaction of domestic economic structure and policy, given the impact of internal shocks (such as productivity and real wage shocks) and external shocks (such as terms of trade and portfolio preference shocks). Other things equal, similarity or co-movement in countries' real effective exchange rates suggests similarity in the structure of their economies, policies, and shocks to their economies. Figure 3 shows JP Morgan estimates of monthly real effective exchange rates for 12 economies in east Asia. There appears to be substantial variation in real effective exchange rate movements. 


\section{Figure 3: JP Morgan Real Broad Effective Exchange Rate Indices in East Asia, 1995 $=100$}

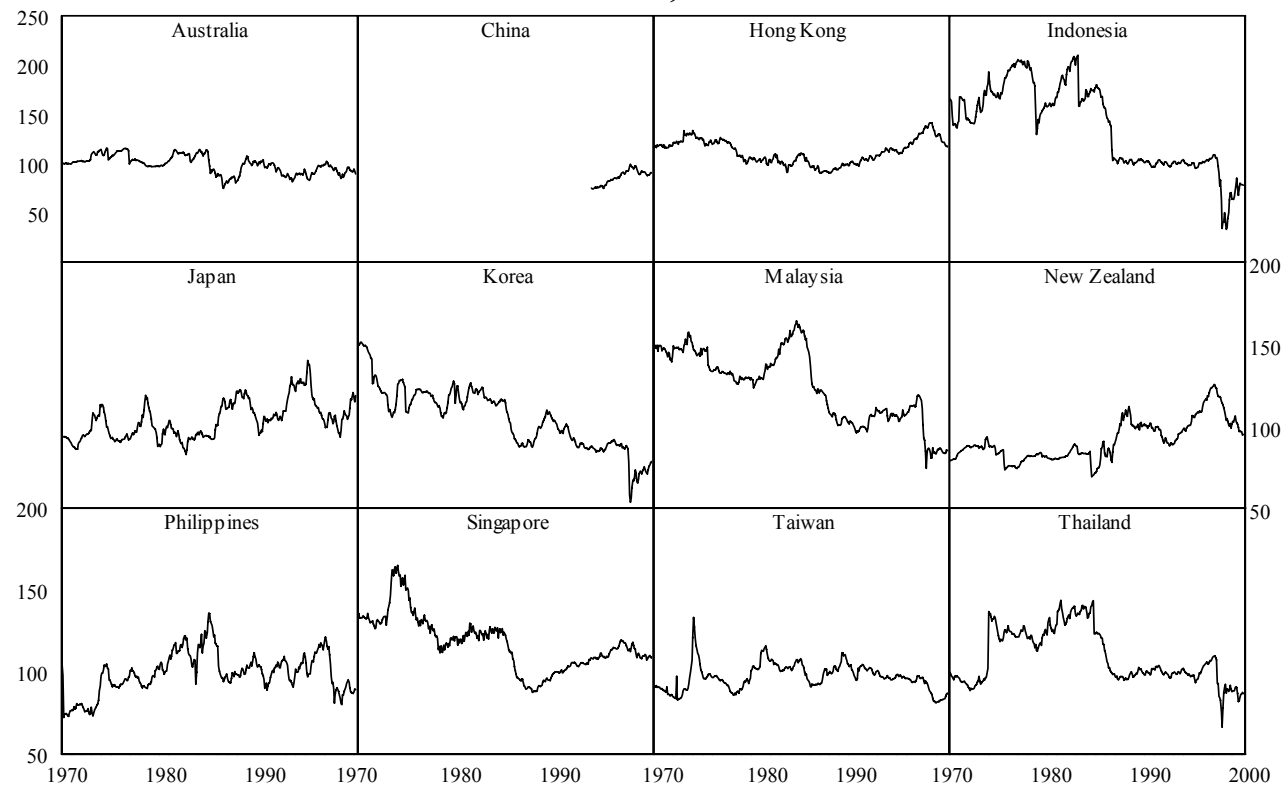

To assess whether there are common regional elements in these real effective exchange rates, common factor analysis was applied to first differences of the series. ${ }^{12}$ Factor analysis is concerned with finding a small number, $q$, of common but orthogonal factors that linearly reconstruct the original $p$ variables,

(1) $x_{i j}=z_{i 1} b_{1 j}+z_{i 2} b_{2 j}+\ldots+z_{i q} b_{q j}+e_{i j}$,

where $x_{i j}$ is observation $i$ of variable $j$ (standardised to have unit variance), $z_{i k}$ is observation $i$ of the common factor $k, b_{k j}$ is the set of linear factor loadings, and $e_{i j}$ is variable $j$ 's unique factor (that is, a factor uncorrelated with the common factors). The factor loading is the weight for each factor, and measures the contribution of that factor to the common variance of the data series. The aim here is to identify and name the common factors in regional real exchange rates by particular country groupings. This is admittedly a subjective process.

Table 8 reports the results, listing the eigenvalue in the first column and loadings of that factor for each country in subsequent columns. ${ }^{13}$ The countries for which a common factor seems to exist are shaded. Results for

\footnotetext{
12 First differences are used because augmented Dickey Fuller tests indicate that all real effective exchange rates in the region over the full sample period have one unit root.

13 The common factors are estimated using Stata 6. The factors are estimated from the principal factor solution, that is, they are based on the prediction of the original covariance matrix. The factor loadings are rotated using an oblique rotation method, promax with power 3 (Rummel 1970). The rotation has a relatively small impact on the size of the factor loadings but does increase clustering.
} 
four periods are reported - the total sample period of 1970 to 1999 , and the sub-periods of the 1970s, 1980s and 1990s. For each period, the "uniqueness" for each country is also reported. A variable's uniqueness is the percentage of its variance that is not explained by common factors.

Table 8: Common Factors in East Asian Regional Real Effective Exchange Rates

\begin{tabular}{|c|c|c|c|c|c|c|c|c|c|c|c|}
\hline Eignevalue & Jpn & Kor & Twn & $\mathrm{HK}$ & Idn & Mys & Phl & Sgp & Thl & Aus & $\mathrm{NZ}$ \\
\hline \multicolumn{12}{|l|}{ 1970-1999 } \\
\hline 1. 2.15 & -0.17 & 0.51 & 0.07 & -0.10 & 0.65 & 0.45 & 0.34 & 0.04 & 0.63 & -0.03 & -0.04 \\
\hline 2. 0.45 & -0.15 & 0.10 & -0.04 & 0.10 & -0.04 & 0.05 & 0.05 & -0.08 & -0.08 & 0.44 & 0.49 \\
\hline 3. 0.31 & 0.16 & -0.21 & -0.42 & -0.18 & 0.14 & 0.17 & -0.22 & -0.09 & -0.29 & -0.07 & 0.13 \\
\hline 4. $\quad 0.25$ & -0.12 & -0.15 & 0.06 & 0.29 & 0.07 & 0.30 & 0.12 & 0.45 & -0.03 & 0.04 & -0.08 \\
\hline uniqueness & 0.82 & 0.65 & 0.79 & 0.85 & 0.58 & 0.61 & 0.70 & 0.77 & 0.48 & 0.78 & 0.80 \\
\hline \multicolumn{12}{|l|}{$1970 s$} \\
\hline 1. 1.37 & -0.04 & 0.35 & 0.55 & 0.20 & 0.16 & -0.15 & 0.25 & 0.08 & 0.69 & 0.20 & -0.05 \\
\hline 2. $\quad 0.78$ & -0.09 & -0.18 & 0.01 & 0.31 & 0.11 & 0.50 & -0.04 & 0.48 & 0.00 & 0.03 & 0.06 \\
\hline 3. 0.44 & -0.08 & 0.05 & -0.01 & 0.00 & -0.11 & 0.35 & 0.03 & -0.10 & -0.06 & 0.31 & 0.63 \\
\hline 4. 0.31 & 0.45 & -0.14 & 0.20 & 0.15 & -0.25 & -0.04 & -0.25 & -0.12 & -0.08 & 0.03 & -0.05 \\
\hline uniqueness & 0.79 & 0.80 & 0.72 & 0.84 & 0.85 & 0.58 & 0.83 & 0.74 & 0.46 & 0.89 & 0.58 \\
\hline \multicolumn{12}{|l|}{$1980 s$} \\
\hline 1. 3.05 & -0.46 & 0.91 & 0.68 & 0.25 & 0.19 & 0.06 & 0.47 & -0.13 & 0.68 & 0.20 & 0.12 \\
\hline 2. $\quad 0.47$ & -0.15 & -0.09 & 0.03 & 0.15 & 0.27 & 0.61 & 0.18 & 0.69 & -0.08 & 0.10 & -0.17 \\
\hline 3. 0.35 & -0.10 & 0.17 & 0.00 & 0.02 & -0.05 & -0.02 & -0.06 & 0.10 & -0.22 & 0.47 & 0.25 \\
\hline uniqueness & 0.67 & 0.26 & 0.51 & 0.87 & 0.81 & 0.57 & 0.63 & 0.64 & 0.56 & 0.72 & 0.91 \\
\hline \multicolumn{12}{|l|}{$1990 \mathrm{~s}$} \\
\hline 1. 3.17 & -0.10 & 0.52 & -0.09 & -0.10 & 0.78 & 0.77 & 0.58 & 0.36 & 0.81 & -0.04 & 0.00 \\
\hline 2. 1.22 & 0.06 & 0.16 & 0.19 & 0.06 & -0.08 & -0.11 & 0.15 & 0.09 & 0.03 & 0.70 & 0.66 \\
\hline 3. 0.34 & 0.58 & -0.08 & -0.13 & -0.56 & 0.08 & 0.03 & -0.01 & -0.07 & -0.05 & 0.00 & 0.05 \\
\hline 4. 0.21 & -0.04 & -0.22 & 0.34 & 0.00 & -0.02 & 0.15 & 0.31 & 0.19 & -0.09 & 0.10 & -0.01 \\
\hline uniqueness & 0.63 & 0.63 & 0.74 & 0.67 & 0.49 & 0.42 & 0.40 & 0.73 & 0.31 & 0.47 & 0.61 \\
\hline
\end{tabular}

Source: Author's calculations using JP Morgan real effective rate indices.

The main common factor in real effective exchange rates does not include the whole region, but only a part of it. While its composition varies somewhat in different periods, it includes only Korea, Indonesia, Malaysia, the Philippines and Thailand. While these economies were the ones mainly affected by the financial crisis in 1997 and 1998, the common factor also tends to be present in other periods. There is no overall general regional common factor in real effective exchange rates. The regional factor loading for Japan is opposite in sign in all periods (and especially in the 1980s), indicating that Japan's real effective exchange rate - and implicitly its economic structure and policies - is fundamentally different from the rest of the region. This assessment is robust to changes in data frequency: the loadings are similar when quarterly or annual, rather than monthly, observations are used for analysis. The result that the loading of the regional factor on Japan is negative even at very low frequencies suggests that this outcome is fundamental, and is not simply the product of some regional currencies largely pegging to the US dollar. 
There are also other, minor common factors. The second common factor is an Australia and New Zealand factor, which is present in all periods (but drops out using annual data over the full sample period). This holds more generally for Australian and New Zealand interest rates, stock prices and exchange rates (de Brouwer forthcoming 2001). Other, considerably smaller common factors are also present, but these are less stable over time.

As an alternative to the common factor analysis above, tests for long-run or cointegrating relationships between JP Morgan regional real effective exchange rates were also conducted, using data from 1990 to 1999. The results are reported in Appendix A. The tests indicate that there are eight separate long-run relationships between the 11 real effective exchange rates of Australia, Indonesia, Japan, Korea, Malaysia, New Zealand, the Philippines, Singapore, Taiwan, Thailand and the United States (Table A1). The cointegrating vectors are not readily interpretable. In the first place, there is a mix of positive and negative signs in each of the eight cointegrating vectors (Table A2). There is also no readily interpretable set of country groupings evident from the marginal significance of the eight error correction terms when they are included in the error correction representation of each country's real effective exchange rate (Table A3).

\section{Broader political and policy issues}

The final problem for a group of countries in deciding whether to adopt a common-basket peg is essentially political. This cannot be understated: it is a "fundamental and indisputable fact that political considerations, rather than purely economic concerns, are the predominant practical determinants of the domain of operation of currency regimes" (Mussa 1997: 217). The political considerations are multi-dimensional and complex.

The first obstacle is that countries would only agree to a formal commonbasket peg if it were clear that it would be in their own interests to do so. Consider, for example, the sorts of issues Singapore would have to face in considering the adoption of a common-basket peg. Singapore is probably one of the countries in the region which would be most disadvantaged. Not only is its own trade structure with Japan, the United States and the European Union unlike the average, but its exports are also more similar to those of the United States and Europe than to those of the rest of the region. Hence, it has less to gain directly from focusing on intra-regional exchange rate stability at the expense of exchange rate stability with the United States and European Union. Of all the members of the ASEAN-5, its real 
effective exchange rate has the least in common with the rates of the other members.

More than this, adopting a common-basket peg would limit Singapore's long-established use of the exchange rate as the instrument in inflation control (Eichengreen and Bayoumi 1999). It may also impede Singapore's role as a regional financial centre - a policy objective that has been given particular prominence in recent years - since it would mean that the Singaporean authorities would have to take a direct and active interest in what was happening in the Singapore-based offshore currency markets of its neighbours. The attraction of Singapore to international banks and securities companies is that while the authorities firmly limit speculative activity in the Singapore dollar, they have a totally off-hands approach to trading in other regional currencies. Putting all these together, it is difficult to see that Singapore would want to support a common-basket peg policy.

The adoption of a common-basket peg system would also require substantial deepening of regional institutional structures and policymaking. The shift to a common-basket peg would require greater policy coordination within the region and the development of a regional coordination mechanism. This would require the resolution of some practical problems. Given the importance that ASEAN members place on a common regional stance, the expansion of membership in ASEAN in 1998 to Burma, Cambodia, Laos and Vietnam, for example, creates a particular problem for a regional currency peg involving ASEAN. On economic grounds, the new members of ASEAN are not primary candidates for inclusion in a regional common-currency arrangement, but it would be hard to exclude them on political grounds.

There has been renewed focus in recent years on developing regional structures to support greater financial cooperation. The creation of ASEAN+3 in 1999, and the agreement to extend central-bank repurchase arrangements within this group in May 2000, suggest greater political willingness to address regional financial issues. But the group would also need to address Taiwan's involvement, as well as the membership of Australia and New Zealand if it is to be truly representative of the region. ${ }^{14}$ As well as the issue of country membership, there is also the substantive issue of what institutional arrangements would be needed to support greater cooperation. Possible institutions are an Asian Monetary Fund or expansion of the Asian Development Bank.

\footnotetext{
14 Australia and New Zealand are well-established and active members of the east Asian central bank grouping, EMEAP.
} 
A group committing to a common-basket peg could not simply be symbolic but would need to agree on some hard issues of economic policy. These include the need to form a fund to support the peg, designing intervention rules for such a fund, agreeing to surveillance by other countries in the region, having a workable system for the extension of credit between central banks, agreeing on the weights for the peg, and establishing terms of reference for realignments between regional currencies as national circumstances change.

Given the diversity in trade patterns and real effective exchange rates within the region, occasional realignment is very likely to occur but this is a very difficult political process to manage since it affects bilateral competitiveness. A well-known difficulty with negotiation of currency realignments is that agreement to realign is seldom timely and speculative pressures are likely to take over (Frenkel and Goldstein 1986; Mussa 1997). The prospect of Korean unification poses particular challenges to future regional currency arrangements, much as German unification did in the early 1990s, and the capital demands of unification imply substantial pressures for higher local real interest rates and an appreciated real exchange rate.

Not only is internal realignment necessary, but so is realignment against the three basket currencies as regional shocks and structural changes occur. These are substantive issues, and the ability of the region to deal with them is not well established. The ASEAN-5, for example, have had a system of repurchase agreements in place between central banks for several decades, but it has not been used since at least the early 1980s. While symbolism is important, a peg will only be viable if there is clear agreement on hard policy issues.

A wider political issue is how the formation of a regional currency group would affect the balance of political influence in the region. The formation of a regional currency group may be perceived as shifting the regional balance of power in favour of Japan. Support for a regional commonbasket peg seems to be strongest in Japan, although it is evident elsewhere in the region. Japanese commentators, such as Murase (2000), see such a peg as the first step in common regional currency arrangements, to be followed in the next decade or so by the creation of an Asian currency unit, based on convertible currencies in the region with the yen as the de facto anchor currency, and culminating in actual currency union. To the extent that policies converge, it is unclear whether countries would be willing for Japan to be the focus. To quote Dornbusch and Park (1999:14) on Japan: "Over the past few years the country has mismanaged the response to 
dramatic balance sheet problems and deflation. The lack of pragmatism, the institutional inflexibility and possibly incompetence make it unsuitable as a centre country."

It is also unclear how countries like China and Korea would respond to a program which provided substantial political profile for Japan, especially if it came with questions about the cost to domestic economic efficiency. There is the added complication that if participation in the peg is initially limited, such that Taiwan is included but China is not, cross-strait tensions may be exacerbated if the move is seen as some sort of demonstration - or encouragement - of independence by Taiwan. These questions would have to be resolved to move forward.

Another precondition for success of a formal common-basket peg is that member countries have to be fully politically committed to the system (Frenkel and Goldstein 1986). Perceptions of relatively weak political commitment of some European governments to the EMS in the early 1990s gave rise to substantial, and mostly irresistible, speculative pressures in European foreign exchange markets at that time (Mussa 1997). Capital is highly mobile and, despite some limits on funding the speculative short foreign currency positions of non-residents, regional financial systems are relatively open. All exchange rate systems are subject to speculative pressures, but fixed exchange rate systems are typically the most vulnerable since they are less easy to adjust when they become misaligned with fundamentals and the authorities essentially guarantee speculators the liquidity to exit their positions with a profit if the value of the currency is changed. To the extent that national policy and economic objectives become inconsistent with the common-basket peg, the system will be tested. These inconsistencies can readily arise.

Pisani-Ferry (1999) argues that a strong political-economy argument in favour of a common-basket peg is that it would increase the transparency of exchange rate policies in the region. But this also makes a formal common-basket peg more vulnerable. When the weights for a peg are well known, any deviation of the actual exchange rate from its predicted pegged value can provide easy profits for speculators. This occurred with the baht in early 1997 and the New Zealand dollar relative to the Reserve Bank of New Zealand's monetary conditions index in 1997 and 1998. Conversely, one reason why speculation against the Singapore dollar is difficult is that the weights in the Monetary Authority of Singapore's effective exchange rate target are not known with precision. 


\section{CONCLUSION}

There are various proposals that east Asia, or some subgroup within the region, adopt formal common currency arrangements. The most prominent proposal at this stage is that countries peg their currencies to a common basket of the yen, dollar and euro (Williamson 2000; Dornsbusch and Park 1999; Murase 2000). A common-basket peg would stabilise countries' average exchange rates against the major currencies. And it would reduce intra-regional exchange rate variability, even eliminating it if countries fixed their currencies to a common-basket peg.

A common-basket peg needs to be robust to be viable. In the current environment of open integrated and sophisticated financial markets and large and variable capital flows, it is imperative that exchange rate regimes be sustainable and robust to shocks and speculation. In the first place, countries will only adopt a common-basket peg if it is clearly in their interests to do so. Moreover, if a regional system of basket pegged exchange rates is or becomes inconsistent with a member country's domestic economic structure or policy regime, it will be tested by speculators, whether they be onshore or offshore.

It is not yet clear that adoption of a common-basket peg would be in the interests of many countries in the region. In the first place, trade patterns vary substantially between countries in the region, and some countries would be disadvantaged relative to their neighbours under a commonbasket peg. The exports of the more developed countries in the region are more similar to those of the major economies than to their regional neighbours, and so it does not make sense to reduce intra-regional exchange rate volatility at the expense of shifts in competitiveness relative to the world's major exporters.

There are other, more general, factors which throw questions over whether a formal common-basket peg would be feasible or deliverable. To the extent that a common-basket peg entails a change in exchange rate regime, it is necessary to show that a peg is superior to the current regime floating exchange rates - to which decision makers have already adapted. A shift to a common-basket peg also presumes that exchange rate volatility adversely affects trade and economic performance, and there is no evidence that exchange-rate volatility per se has affected trade performance in east Asia. Pegging also affects the adjustment of the real exchange rate, forcing it to occur through the price level rather than the nominal exchange rate. This is relatively inefficient when inflation is persistent and when variable inflation is itself costly to economic efficiency. 
The robustness of a regional exchange rate system depends on how common are individual country's economic structures, policies, and internal and external shocks. Evidence from analysis of common factors affecting real effective exchange rates in the region and cointegration analysis suggest that economic structures, policies and shocks are heterogeneous. Of course, the adoption of common currency arrangements may alter this. The robustness of such a regime also depends on a range of political factors about which there are important questions - a commonbasket peg appears to conflict with other domestic policy objectives, it is difficult to show that countries are prepared to make substantive policy decisions collectively rather than individually, and a common-peg basket may not suit some countries' strategic interests in the region. Without very firm political commitment, a common-basket peg would not be viable. To the extent that outcomes under a common-basket peg conflict with national economic and policy interests, the system is vulnerable to speculative attack. East Asia would not appear to be an obvious candidate for a formal common-basket peg arrangement at this stage.

Alternative exchange rate regimes need to be compared to the system that is currently in place. During the east Asian financial crisis, most countries in the region abandoned implicit pegging to the dollar and moved to greater exchange rate flexibility, typically to floating rate systems. As economies have recovered, the authorities in some countries have attempted to contain the appreciation of their currencies relative to the dollar. To the extent that this marks a return to implicit dollar pegging, these countries may be recreating the very conditions which led to the financial crisis in 1997. While formal pegging to a common basket does not seem like a good idea for countries in east Asia, nor is implicit dollar pegging. Williamson's critique of implicit dollar pegging by east Asian countries is right, even though his remedy needs to be subject to a good deal more careful scrutiny. 


\section{Appendix A: Cointegration of JP Morgan Real Effective Exchange Rates, 1990-1999}

Estimated using Microfit 4.0.

Table A1: Number of Cointegrating Vectors

\begin{tabular}{cccc}
\hline \hline null & alternative & Max eigenvalue & Trace statistic \\
\hline $\mathrm{r}=0$ & $\mathrm{r}=1$ & $170.26^{* *}$ & $618.07^{* *}$ \\
$\mathrm{r}<=1$ & $\mathrm{r}=2$ & $94.88^{* *}$ & $447.81^{* *}$ \\
$\mathrm{r}<=2$ & $\mathrm{r}=3$ & $86.80^{* *}$ & $352.93^{* *}$ \\
$\mathrm{r}<=3$ & $\mathrm{r}=4$ & $68.53^{* *}$ & $266.13^{* *}$ \\
$\mathrm{r}<=4$ & $\mathrm{r}=5$ & $56.70^{* *}$ & $197.60^{* *}$ \\
$\mathrm{r}<=5$ & $\mathrm{r}=6$ & $21.20^{* *}$ & $140.90^{* *}$ \\
$\mathrm{r}<=6$ & $\mathrm{r}=7$ & $36.70^{*}$ & $99.70^{* *}$ \\
$\mathrm{r}<=7$ & $\mathrm{r}=8$ & 23.96 & $63.00^{* *}$ \\
$\mathrm{r}<=8$ & $\mathrm{r}=9$ & 20.31 & $39.04^{*}$ \\
$\mathrm{r}<=9$ & $\mathrm{r}=10$ & 10.69 & 18.73 \\
$\mathrm{r}<=10$ & $\mathrm{r}=11$ & 8.04 & 8.04 \\
\hline \hline
\end{tabular}

Notes: $* *$ and $*$ indicate significant at the 5 and 10 per cent levels.

Table A2: Eight Cointegrating Vectors, standardised on the yen real effective exchange rate

\begin{tabular}{lcccccccc}
\hline \hline & No. 1 & No. 2 & No. 3 & No. 4 & No. 5 & No. 6 & No. 7 & No. 8 \\
\hline Japan & -1.00 & -1.00 & -1.00 & -1.00 & -1.00 & -1.00 & -1.00 & -1.00 \\
Korea & 2.67 & 3.40 & 3.48 & -4.10 & -56.41 & 0.29 & 0.00 & -0.42 \\
Taiwan & 2.71 & 1.13 & 0.59 & 2.61 & -7.07 & 0.83 & -1.28 & 0.14 \\
Indonesia & 1.03 & 0.03 & -1.70 & 1.69 & 7.43 & -0.34 & -0.50 & 0.30 \\
Malaysia & 0.73 & -3.02 & 4.46 & -3.56 & -17.80 & 0.55 & 0.20 & 0.46 \\
Philippines & -1.80 & 1.18 & -2.14 & 0.51 & 5.89 & -1.77 & 1.59 & 0.39 \\
Singapore & 6.42 & 3.81 & -1.18 & -2.82 & -66.35 & 5.52 & -4.21 & -1.33 \\
Thailand & -6.39 & -0.05 & -2.97 & 2.71 & 57.54 & -0.13 & -0.32 & 0.51 \\
Australia & -0.28 & -5.78 & -0.08 & -2.32 & 17.13 & 2.20 & 0.01 & -0.87 \\
New Zealand & 0.30 & 1.14 & -0.29 & 1.55 & -9.04 & -3.25 & -0.70 & -0.06 \\
United States & 2.95 & 3.70 & -0.92 & -0.70 & -13.00 & -3.84 & -0.96 & -0.76 \\
\hline \hline
\end{tabular}

Table A3: Marginal Significance of the Eight Cointegrating Vectors in Individual Country ECMs

\begin{tabular}{lcccccccc}
\hline \hline & No. 1 & No. 2 & No. 3 & No. 4 & No. 5 & No. 6 & No. 7 & No. 8 \\
\hline Japan & 0.62 & 0.98 & 0.02 & 0.87 & 0.24 & 0.37 & 0.18 & 0.57 \\
Korea & 0.00 & 0.22 & 0.00 & 0.00 & 0.58 & 0.38 & 0.99 & 0.98 \\
Taiwan & 0.38 & 0.00 & 0.03 & 0.82 & 0.05 & 0.29 & 0.36 & 0.11 \\
Indonesia & 0.00 & 0.04 & 0.58 & 0.41 & 0.81 & 0.33 & 0.25 & 0.65 \\
Malaysia & 0.04 & 0.00 & 0.11 & 0.00 & 0.95 & 0.11 & 0.43 & 0.81 \\
Philippines & 0.38 & 0.17 & 0.11 & 0.00 & 0.58 & 0.13 & 0.01 & 0.29 \\
Singapore & 0.16 & 0.58 & 0.33 & 0.16 & 0.97 & 0.02 & 0.47 & 0.15 \\
Thailand & 0.00 & 0.67 & 0.03 & 0.01 & 0.11 & 0.02 & 0.26 & 0.77 \\
Australia & 0.44 & 0.02 & 0.05 & 0.15 & 0.00 & 0.07 & 0.64 & 0.13 \\
New Zealand & 0.08 & 0.21 & 0.91 & 0.82 & 0.33 & 0.74 & 0.43 & 0.08 \\
United States & 0.05 & 0.31 & 0.01 & 0.49 & 0.74 & 0.75 & 0.51 & 0.00 \\
\hline \hline
\end{tabular}




\section{References}

Alba, P., A. Bhattacharya, S. Claessons, S. Ghosh and L. Hernandez (1999), "Volatility and Contagion in a Financially Integrated World: Lessons From East Asia's Recent Experience", in Gordon de Brouwer (ed.) Asia Pacific Financial Deregulation, London, Routledge, 9-65.

Argy, V., W. McKibbin and E. Siegloff (1989), "Exchange-Rate Regimes for a Small Economy in a Multi-Country World", Princeton Studies in International Finance, No. 67.

Bayoumi, T. and P. Mauro (1999), "The Suitability of ASEAN for a Regional Currency Arrangement”, IMF Working Paper WP/99/162.

Bayoumi, T., B. Eichengreen and P. Mauro (2000), "On Regional Monetary Arrangements for ASEAN", Centre for Economic Policy Research, Discussion Paper No. 2411.

Council on Foreign Exchange and Other Transactions (1999), "Internationalization of the Yen for the $21^{\text {st }}$ Century", Tokyo, April 20, http://www.mof.go.jp/english/if/elb064a.htm.

de Brouwer, G.J. (1999), Monetary Policy and the Structure of the Capital Account in Australia", in Bank of Mexico, Monetary Policy and the Structure of the Capital Account, Proceedings of the Thirteenth Pacific Basin Central Bank Conference, 31-63.

de Brouwer, G.J. (forthcoming 2001), "Integrating Financial Markets in East Asia", in Globalization in the New Millennium, Routledge, London.

Dornbusch, R. (1976), "Expectations and Exchange Rate Dynamics", Journal of Political Economy, 84(6), 1161-1176.

Dornbusch, R. and Y.C. Park (1999), "Flexibility or Nominal Anchors?", in Stefan Collignon, Jean Pisani-Ferry and Yung Chul Park (eds.), Exchange Rate Policies in Emerging Asian Countries, Routledge, London, 3-34.

Eichengreen, B., P. Masson, M. Savastano and S. Sharma (1999), "Transition Strategies and Nominal Anchors on the Road to Exchange Rate Flexibility", Princeton University, Essays in International Finance, No. 213.

Eichengreen, B. and T. Bayoumi (1999), "Is Asia an Optimum Currency Area? Can It Become One?", in Stefan Collignon, Jean Pisani-Ferry and Yung Chul Park (eds.), Exchange Rate Policies in Emerging Asian Countries, Routledge, London, 347-366. 
Frankel, J.A. (1991), "Is a Yen Bloc Forming in Pacific Asia?", in R. O,Brien (ed.), Finance and the International Economy: The AMEX Bank Review Prize Essays, London, Oxford University Press, pages.

Frankel, J.A. and S.J. Wei (1994), "Yen Bloc or Dollar Bloc? Exchange Rate Policies of the East Asian Economies", in Takatoshi Ito and Anne Kruger (eds.), Macroeconomic Linkage: Savings, Exchange Rates, and Capital Flows, University of Chicago Press, Chicago, 295-329.

Frenkel, J. and M. Goldstein (1986), "A Guide to Target Zones", IMF Staff Papers, 33, 633-673.

Gagnon, J.E. (1993), "Exchange Rate Variability and the Level of International Trade", Journal of International Economics, 34, 269-287.

Goto, J. and K. Hamada (1994), "Economic Preconditions for Asian Regional Integration", in Takatoshi Ito and Anne Kruger (eds.), Macroeconomic Linkage: Savings, Exchange Rates, and Capital Flows, University of Chicago Press, Chicago, 359-388.

Isard, P. (1995), Exchange Rate Economics, Cambridge, Cambridge Surveys of Economic Literature, Cambridge University Press.

Ito, T., E. Ogawa and Y.N. Sasaki (1998), "How Did the Dollar Peg Fail in Asia?", NBER Working Paper No. 6729.

Kawai, M. and S. Akiyama (2000), "Implications of the Currency Crisis for Exchange Rate Arrangements in Emerging East Asia", mimeo, World Bank, Washington, D.C.

Kawai, M. and S. Takagi (2000), "The Strategy for a Regional Exchange Rate Arrangement in Post-Crisis East Asia: Analysis, Review and Proposal", mimeo, World Bank, Washington, D.C.

Kenen, P. (1997), "Preferences, Domains, and Sustainability", American Economic Review, American Economic Association Papers and Proceedings, 87(2), 211-213.

Kuroda, H. (2000), "Vice Minister's Speech on the Future International Financial Architecture and Regional Financial Cooperation", Public Seminar at the Australian National University, 17 February.

Moon, W.S., Y.S. Rhee and D.R. Yoon (2000), "Asian Monetary Cooperation: A Search for Regional Monetary Stability in the Post Euro and the Post Asian Crisis Era", Bank of Korea, Economic Papers, 3(1), 157-193. 
Moon, W.S. and Y.S. Rhee (forthcoming 2001), "Foreign Exchange market Liberalization Policies in Korea: Past Assessment and Future Options", in Lee (ed.), Globalization in the New Millenium, London, Routledge.

Mundell, R. (1961), "The Theory of Optimum Currency Areas", American Economic Review, 51, 657-665.

Murase, T. (2000), Ajia Antei Tsuukaken: Yuroo ni Manabu Yen no Yakuwari (The Asian Zone of Monetary Stability: Lessons from the Euro and Role of the Yen), Tokyo, Keiso Shobo.

Mussa, M. (1990), "Exchange Rates in Theory and in Reality", Princeton University, Essays in International Finance, No. 179.

Mussa, M. (1997), "Political and Institutional Commitment to a Common Currency", American Economic Review, American Economic Association Papers and Proceedings, 87(2), 217-220.

Mussa, M., P. Masson, A. Swoboda, E. Jadresic, P. Mauro and A. Berg (2000), Exchange Rate Regimes in an Increasingly Integrated World, IMF, April.

Obstfeld, M. and K. Rogoff (1995), "The Mirage of Fixed Exchange Rates", Journal of Economic Perspectives, Fall.

Ito, T., E. Ogawa and Y.N. Sasaki (1998), "How Did the Dollar Peg Fail in Asia?", NBER Working Paper No. 6729.

Ogawa, E. and T. Ito (2000), "On the Desirability of a Regional Basket Currency Arrangement", mimeo, March.

Ogawa, E. (2000), "Cause, Effects and Lessons from the Asian Crisis: From the Viewpoint of the Exchange Rate System", paper presented at the $29^{\text {th }}$ Annual Conference of Economists of the Economic Society of Australia, 3-5 July, Gold Coast.

Pisani-Ferry, J. (1999), Discussion on The Case for a Common Currency Basket", in Stefan Collignon, Jean Pisani-Ferry and Yung Chul Park (eds.), Exchange Rate Policies in Emerging Asian Countries, Routledge, London, 344-346.

Rummel, R.J. (1970), Applied Factor Analysis, Northwestern University Press, Evanston.

Sakakibara, E. (1999), "The Lessons of the Financial Crisis", paper presented at the Round Table on Securities Market Reform in the Face of the Asian Financial Crisis, 8 April. 
Turnovsky, S.J. (1982), "A Determination of the Optimal Currency Basket", Journal of International Economics, 12, 333-354.

Wei, S. (1999), "Currency Hedging and Goods Trade", European Economic Review, 43, 1271-1294.

Williamson, J. (1999), "The Case for a Common Basket Peg for East Asian Currencies", in Stefan Collignon, Jean Pisani-Ferry and Yung Chul Park (eds.), Exchange Rate Policies in Emerging Asian Countries, Routledge, London, 327-343.

Yoshino, N., S. Koji and A. Suzuki (2000) "Basket Peg, Dollar Peg and Floating: A Comparative Analysis of Exchange Rate Regimes", Keio University, mimeo. 